INTERNATIONAL DESIGN CONFERENCE - DESIGN 2018

https://doi.org/10.21278/idc.2018.0292

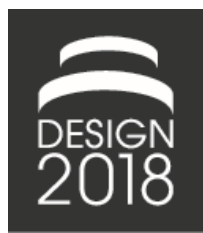

\title{
PROPOSITION OF GUIDELINES FOR ASSESSING INNOVATION IN THE DESIGN AND PRODUCTION OF PAPERBOARD CONSUMER PACKAGING
}

\author{
R. M. Sastre, I. C. de Paula and M. E. S. Echeveste
}

\begin{abstract}
When thinking of innovation applied to packaging, it becomes evident that there is a profusion of propositions of an applied nature to improve and benefit. However, the literature does not present guidelines that help assessing the main innovation factors applied to paperboard packaging. This article aimed to identify guidelines for assessing innovation in the design and production of paperboard consumer packaging which could be used to identify the type and intensity of incident innovation factor(s). The study used a qualitative/descriptive methodological approach and literature review.
\end{abstract}

Keywords: packaging, design creativity, idea generation, design methods, innovation

\section{Introduction}

Designers have a relevant role in the process of making different products and services in companies that seek innovation and competitiveness. They contribute to this task by proposing creative and original functional solutions, use of materials, technologies and processes, productivity and sustainability, among others, to add new values to products and services that meet the needs of the target public (Mestriner, 2002). Innovation enabled human survival, involving the mind to process information, intellect, attitude, intelligence and motivation. In the economic sphere, innovation appears with the introduction of a new good; a new production method; the opening of a new market or the discovery of a new source of raw material. It can be a specific tool for entrepreneurs, the means by which they exploit change as an opportunity to be different. Innovation should also be understood as the development of a culture of innovation within the company, bringing a steady stream of smaller and incremental innovations to the market. It is the ability to transform the low performance of a new idea (Drucker, 1986; Schumpeter, 1988; Christensen, 1997; Mattos et al., 2010; Bezerra, 2011; Kotler and Trías de Bes, 2011).

Innovation can be measured by the degree of novelty involved; its intensity can be radical or incremental. Radical innovation transforms the way things are seen or used, it represents a drastic change in the way in which a product/packaging or service is consumed, modifying the current business model. Incremental innovation can occur by promoting small improvements in products, packaging or product lines. Generally they represent small advances to the benefits perceived by the consumer and do not significantly modify current business models (Tidd et al., 2008).

The focus of this article is innovation in paperboard consumer packaging. Packaging is defined as wrappers, containers or any form of removable or non-removable packaging intended to cover, pack, protect, maintain or facilitate the marketing of products. The packaging that is found in supermarkets and stores results from the actions of a complex and multidisciplinary system, from the performance of several actors from different areas that develop collaborative activities. Consumer packages are those that have direct contact with the consumer, exercising, among other aspects, a persuasive role. They are part of the product, from the time 
they are sold until they are used. Paperboard is the most common material used for these packages, made of a multilayer of cellulose, resulting from the union of several superimposed layers of paper, equal or different, that adhere to each other by compression (Pereira, 2003; Mestriner, 2005; Gurgel, 2007; Camilo, 2011).

Studies on innovation in packaging generally focus on sustainability and recycling guidelines, seeking to implement new materials and textures, paints and varnishes, shapes and sizes, opening systems, among others. However, the literature does not present guidelines to assess the degree of innovation in paperboard consumer packaging. The advantage of assessing innovation is to provide support for its actual implementation in the search for competitiveness. Thus, given the importance of problematizing innovation in the design and production of paperboard consumer packaging, the following research question was set: What are the guidelines for innovation in paperboard packaging?

This article identified guidelines for assessing innovation in the design and production of paperboard consumer packages that can be used to help identify the type and intensity of incident innovation factor(s). These guidelines contribute to make innovation applicable to design projects and to be perceived by consumers.

This study adopted a qualitative/descriptive methodological approach, and literature review. First, concepts and theories on innovation applied to Design are described. With this initial stage it was possible to compose the guidelines used to assess innovation in packaging. Finally, we selected for analysis the paperboard packages awarded in the Gold category by ABRE (Brazilian Packaging Association), in its last edition, in 2016.

\section{Analysis of concepts and theories}

This section examines the perspectives on innovation by authors of the area of Design, as follows: Mestriner (2002); Camilo (2009); Bonsiepe (2011); Verganti (2012). Innovation in Design is, according to Bonsiepe (2011), an indicator for the promotion of competitiveness in the globalized world. The author presents a list of essential factors for innovation in Design, called "vectors" or "driving forces" (Table 1). This proposition is not intended to be complete, but should be seen more as an attempt to show the depth of the innovative activities undertaken by designers.

Table 1. Vectors or driving forces for design innovations (source: adapted from Bonsiepe, 2011)

\begin{tabular}{|l|l|l|}
\hline \multicolumn{1}{|c|}{ Vector or driving force } & \multicolumn{1}{c|}{ Concept } & \multicolumn{1}{c|}{ Examples } \\
\hline Technology-based innovation & $\begin{array}{l}\text { New raw materials, new } \\
\text { production processes }\end{array}$ & Green plastic, mixed materials \\
\hline User-based innovation & $\begin{array}{l}\text { Artifacts that make interaction } \\
\text { with the user easier }\end{array}$ & $\begin{array}{l}\text { Sardine cans with a device for opening } \\
\text { them by hand }\end{array}$ \\
\hline Form-based innovation & New formats for existing products & Retractable tables and chairs \\
\hline Invention-based innovation & $\begin{array}{l}\text { Radical innovation, changing } \\
\text { existing concepts }\end{array}$ & Microwave oven \\
\hline $\begin{array}{l}\text { Innovation based on symbolic } \\
\text { value or status }\end{array}$ & $\begin{array}{l}\text { Artifacts give status to those who } \\
\text { have them }\end{array}$ & Fruit juicer by Philippe Starck \\
\hline Tradition-based innovation & Manifestation of a culture & Typical Peruvian embroidery \\
\hline $\begin{array}{l}\text { Innovation based on mechanical } \\
\text { engineering }\end{array}$ & New machinery and equipment & $\begin{array}{l}\text { Agricultural machines, hospital } \\
\text { equipment }\end{array}$ \\
\hline Ecology-based innovation & Sustainable artifacts & Reusable packages. \\
\hline Branding-based innovation & A brand generating new concepts & Devassa Beer (Brazil) \\
\hline Trend-based innovation & Piggyback on a current concept & Retro or vintage designs \\
\hline Art-based innovation & $\begin{array}{l}\text { Sculptures or paintings applied to } \\
\text { artifacts }\end{array}$ & $\begin{array}{l}\text { Famous pictures applied as a print to } \\
\text { artifacts }\end{array}$ \\
\hline Criticism-based innovation & Reactions to existing artifacts & The Pop Art Movement \\
\hline
\end{tabular}

The concept of innovation according to Bonsiepe (2011) is currently seen as indisputable. However, little is said about the content of innovation. Regarding design, innovation happens with small changes in form to radical innovation. According to Verganti (2012), design-driven innovation is possible, primarily because any type of innovation is strongly linked to creative ability, that is, the ability developed by designers. 
Based on the literature, two findings by management research in the last decades stand out. The first is that radical innovation, while presenting greater risks, is the greatest source of competitive advantage in the long run. The second finding was that people do not buy products, but meanings. People seek products based on emotional, psychological, and sociocultural reasons, as well as just practical reasons. Companies must then think beyond characteristics, functions and performance and understand the main factors that motivate the acquisition and maintenance of products.

Thus, innovation has been focused on two strategies: the first relates to major advances in product performance with the use of state-of-the-art technology, and the second refers to the improvement of product solutions through a more elaborate analysis of needs. The first is part of the territory of radical technologybased innovation, and the second, of incremental market-based innovation. The author attributes a third strategy: design-driven innovation, that is, radical innovation in meaning (Verganti, 2012).

An example of the application of this type of innovation was described by Verganti (2012) using the Metamoforsi lamp of the Italian factory Artemide. It's a totally different light fixture; it is a sophisticated system that changes the atmosphere with colored lights that can be controlled and adapted according to the desires and needs of the customer. The company's view was that ambiance lighting, especially as regards colors and nuances, has a great influence on the psychological state of people and their interaction; so Artemide created a system that emitted a light that made people feel better. The Metamoforsi lamp revolutionized the reason why people buy lamps, totally changing its meaning.

Design-driven innovation explains the value of creating competitive and sustainable advantages and the challenges arising from it. It focuses mainly on the interaction between radical innovation of meaning and radical innovation of technologies: the field in which technology-based innovation and design-based innovation overlap (Figure 1).

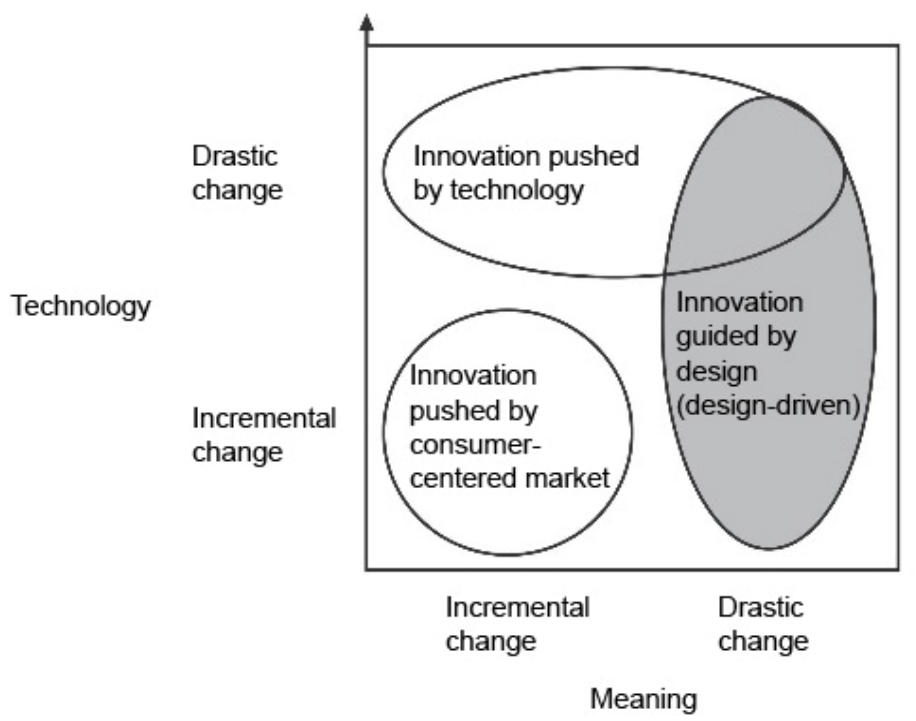

Figure 1. Design-driven innovation strategies as a radical change of meanings (source: Verganti, 2012)

Design-driven innovation does not originate in the market, but creates a market. It generates products and services with expressive profit margin, adding value to the brand and helping the company grow. Designdriven innovation is not based on creativity, unlike the conventional activity of designers, but on defining a strategic direction and investing in intangible assets. It is, therefore, a work for specialists. It can propose meanings that have not been thought of by consumers, but which ultimately attract them. The author states that design is not only a way of creating beautiful shapes, but a way to anticipate needs and propose visions. Bringing the concept of design-driven innovation to the context of packaging, an opportunity for the designer to propose innovation is through: (i) Packaging materials and technologies - Insert new materials into the product category; invest in product packaging and packaging technology; (ii) Opening and closing devices - Improvements in opening and closing; practicality and convenience; eliminate the use of tools such as scissors or openers; devices to close packages being used; (iii) Colors and textures - New paints, 
varnishes and pigments; surface treatments such as metallization; holographic and textured films; and (iv) Images and visual effects - Images alter or create new contexts for product positioning; new visual languages; a good example of inserting famous characters and representing the product as sources of innovation is the (Mestriner, 2002) packaging. Sources for innovation in packaging are found in the packaging industry, since there is a constant search for different solutions among competitors. These companies examine the national and international market for what is being used in packaging in all product categories and visit specialized fairs, which are also actions to seek resources, as industries take advantage of these events to launch their innovations (Mestriner, 2002).

Camilo (2009) proposes the mapping of innovation in packaging through "directions" based on (5) five market trends that seek to meet consumer needs: convenience; health; safety; lifestyle and sustainability: (i) Cost reduction - Improve packaging and packaging production processes; replace raw materials and optimize structural projects; (ii) Increased shelf life - Preserve the physical and visual integrity of the packaging and optimize the spaces in the shelves; (iii) Increase in safety and security - Maintain the integrity of the product and the consumer and avoid leaks or waste in the logistics process;(iv) Keep product fresh longer - Improve barriers against light, moisture and other weather-related problems; (v) Increased practicality and functionality in transport or storage - More compact or symmetrical packages facilitate and reduce logistical costs; (vi) Facilitate the use - Improvement in the ergonomic aspects of the packaging, opening and closing; (vii) Improve recycling or enable its reuse - Avoid mixing materials, use renewable sources; design for sustainable aspects and facilitate recycling; (viii) Improve presentation - Special finishes; surface treatment; transmit innovation and performance to the product; (ix) Follow the users' lifestyle and habits - Adapt the package to the habits of the user through its shape and form; opening and closing; special materials and improvements to the interaction of the packaging with special-needs consumers; and (x) Delight consumers with accessories - Insert a "prize" in the packaging, or make the package reusable as something else.

According to the author, the directions can occur simultaneously, and the more directions are taken in the same package, the better. Innovative packaging helps conquer competitive spots in stores, increasing the value of goods and, consequently, their profitability. Next, we present Table 2, which summarizes the main concepts mentioned in this section about innovation from a design perspective. The authors are Mestriner (2002), Camilo (2009), Bonsiepe (2011), and Verganti (2012) to assist in proposing the assessment criteria presented in the following chapter. This choice was made because these authors are closer to the reality of Design and have offered subsidies to promote innovation applied to packaging. The concepts were paired according to the proposed categorization, with proper identification of the authors.

Table 2. Analytical chart of the ideas and concepts that collaborate to support the innovation assessment criteria for packaging design

\begin{tabular}{|c|c|c|}
\hline Concept & Authors & Proposed categories \\
\hline Technology, invention and mechanical engineering & Bonsiepe & Technological aspects \\
\hline Packaging materials and technology & Mestriner & Technological aspects \\
\hline Technology-driven innovation & Verganti & Technological aspects \\
\hline Ecology & Bonsiepe & Environment and sustainability \\
\hline To improve recycling and facilitate reuse & Camilo & Environment and sustainability \\
\hline Symbolic value or status, tradition, branding, trend, art and criticism. & Bonsiepe & Market \\
\hline $\begin{array}{l}\text { Cost reduction; improving the appearance and delighting the } \\
\text { consumer with a device. }\end{array}$ & Camilo & Market \\
\hline Market-driven innovation & Verganti & Market \\
\hline Form & Bonsiepe & Morphology \\
\hline Colors and textures, images and visual effects & Mestriner & Morphology \\
\hline \multirow[t]{2}{*}{ Design-driven innovation } & \multirow[t]{2}{*}{ Verganti } & Morphology \\
\hline & & Environment and Sustainability \\
\hline User & Bonsiepe & Usability \\
\hline $\begin{array}{l}\text { Increased shelf life; increased protection and security; keep product } \\
\text { fresh longer; contextualize the lifestyle and habits of the users and } \\
\text { facilitate the use. }\end{array}$ & Camilo & Usability \\
\hline Opening and closing devices & Mestriner & Usability \\
\hline
\end{tabular}




\section{Methodology}

This is a qualitative, descriptive and interpretive research, with the use of literature review based on published materials, including traditionally printed materials, such as books, magazines, newspapers, theses, dissertations and annals of scientific events, and new media such as CDs, magnetic tapes, materials made available through the Internet, among others.

The model proposed for the literature review, adapted from Gil (2010), consists of three (3) steps: analysis of concepts and theories, categorization, and testing and interpretation. The analysis of concepts and theories began by mapping and analyzing studies from stricto sensu University programs in Design from Brazil which researched packaging and innovation, to find the theoretical framework adopted by these dissertations and theses (authors, theories and concepts). From this preliminary analysis, it was possible to select the authors and their contributions for the literature review. The corpus selected for this study totaled nine hundred and sixty-four (964) papers, from seventeen (17) Brazilian Design graduate courses, with twenty-eight papers on packaging and thirty-seven on innovation.

It is assumed that the concept of innovation is not stagnant and that there are several approaches to this theme. In the categorization stage, we sought to find points of convergence between these perspectives. The guidelines resulting from this study originated from a lexical classification according to closely related meanings, with the pairing of synonyms. It should be noted that these guidelines do not constitute a positivist method for the analysis of Packaging Innovation. Rather, they provide a framework of the main aspects that should be observed according to theorists who study the subject.

Finally, the testing and interpretation was carried out by analyzing carton packages awarded in the Gold category by ABRE (Brazilian Packing Association), in its last edition, held in 2016. To assist in this analysis, the authors used an instrument containing the criteria and sub-criteria created in the previous section. This instrument also considered the intensity of innovation (radical or incremental). The ABRE 2016 prize received 300 packages in this edition, totaling seventy-eight (72) winners, of which twentytwo (22) were Gold, twenty-one (21) Silver and twenty-six (26) Bronze. The analysis considered paperboard packaging classified in the Gold category.

\section{Categorization}

This step describes the proposed guidelines to assist in the assessment of packaging innovation. They were selected from the concepts and theories presented previously.

\subsection{Technology aspects}

This guideline addresses innovations relevant to materials, production processes and technological advances in packaging design. Bonsiepe (2011) refers in its "vectors for design innovations" to technology-based innovation, referring to new raw materials and production processes. Mestriner (2002) addresses this issue in the "fields where to seek innovation" as materials and packaging technologies, through inserting new materials in the category in which the product is found and investing in product packaging and packaging technology. Verganti (2012) points out the technological aspects as "technology-based innovation", referring to the new materials and processes available.

Table 3 shows the sub-criteria in the left column. and in the right column, the recommendations for innovation assessment regarding technological aspects. However, these recommendations do not exhaust the possibilities of analysis, but guide and clarify relevant points to be observed. 
Table 3. Technological aspects sub-criteria and recommendations

\begin{tabular}{|c|c|}
\hline Sub-criteria & Recommendations \\
\hline $\begin{array}{l}\text { Materials } \\
\text { Refers to innovations relevant to } \\
\text { new materials launched on the } \\
\text { market, or to unusual uses and } \\
\text { combinations. Materials are the } \\
\text { printing substrates (papers, paints } \\
\text { and varnishes). }\end{array}$ & $\begin{array}{l}\text { Identify the use of special papers in the manufacture of packaging, } \\
\text { such as waterproof, recycled or with some component applied in its } \\
\text { composition, like plant seeds or aromas. } \\
\text {-Verify the use of special color inks such as metallic, fluorescent or a } \\
\text { custom color scale. The use of varnishes applied throughout the } \\
\text { printed area or in specific areas (localized varnish) that provides } \\
\text { special effects to the packaging. } \\
\text { - Identify papers produced by combining materials, such as plastic } \\
\text { and inorganic resins, which make the paper impermeable; the use of } \\
\text { fabrics in the composition of the paper to give greater strength, and } \\
\text { metallized papers or with aluminum. } \\
\text { - Consider the use of plastic closing systems in paper packaging, as } \\
\text { in the case of Tetra Pack, that uses round plastic closures in their } \\
\text { packaging. }\end{array}$ \\
\hline $\begin{array}{l}\text { Production processes } \\
\text { Refers to the innovations related to } \\
\text { the production of paperboard } \\
\text { packaging by graphic process; new } \\
\text { equipment available on the market } \\
\text { and production methods. The } \\
\text { graphic production process is the } \\
\text { set of operations that generate } \\
\text { printed materials (prepress, print } \\
\text { and post-print). }\end{array}$ & $\begin{array}{l}\text {-Investigate the related to the packaging pre-printing stage, such as } \\
\text { special reticles (points per inch that form the process of color } \\
\text { selection); increase image sharpness; imposition software (assembly } \\
\text { of the final art in the technical plan of the packaging); and monitor } \\
\text { the quality of the print. } \\
\text { - Invest in printing processes that provide greater flexibility to work } \\
\text { with various types of substrates, advance the quality of the print and } \\
\text { increase the number of colors in one package. } \\
\text { - Think of special finishes with cutting and creasing matrices } \\
\text { (knives); applying windows and displays; using glossy, frosted or any } \\
\text { other textured plastic laminations (such as PROLAN); hot-stamping, } \\
\text { which are metallized films transferred to paper through heat pressure; } \\
\text { use reliefs (male and female); use embossing, which is a texture } \\
\text { produced in the paper through pressure with rolls with several } \\
\text { drawings; use special collages; use props like ribbons, elastics and } \\
\text { eyelets, among others. }\end{array}$ \\
\hline $\begin{array}{l}\text { New technologies } \\
\text { Refers to innovations related to } \\
\text { technological advances from other } \\
\text { areas of knowledge that can be } \\
\text { added to the packaging } \\
\text { manufacturing process. }\end{array}$ & $\begin{array}{l}\text { - Pay attention to nanotechnology, which is the manipulation of } \\
\text { matter in an atomic and molecular level, conferring important } \\
\text { characteristics to the packaging as impermeability to gases and water } \\
\text { and greater resistance to oil, among others. } \\
\text { - Use of smart devices for monitoring, indicating or testing } \\
\text { information about the quality or condition of the environment that } \\
\text { may affect the durability or safety of the product. } \\
\text { - Verify active systems that interact with the product, such as } \\
\text { antimicrobials, microwave systems (used for popcorn) and oxygen } \\
\text { sinks (used to increase food shelf life). }\end{array}$ \\
\hline
\end{tabular}

\subsection{Environment and sustainability}

This guideline addresses innovations relevant to the environmental issues surrounding packaging. These are actions applicable to projects that observe the product life cycle, reduction of materials, processes and pollution, the reuse of packaging and actions that facilitate recycling. Bonsiepe (2011) refers to it in his "vectors for design innovations" as ecology-based innovation, promoting sustainable artifacts through design. Camilo (2009) presents this issue in "directions to seek innovation" as improvements in recycling and ease of reuse, avoiding mixing materials, using renewable sources and designing in a way that is compatible with the life cycle of the packaging. Verganti (2012) points out aspects related to the environment and sustainability as "design-driven innovation", as a trend towards the generation of innovation. For Peltier and Saporta (2009), the reeducation and minimization of the results of the discard of packages are based on a recipe for sustainable design based on three pillars: reduce, reuse and recycle. 
This concept must be applied in each stage of the packaging life cycle, from the extraction of the raw materials, to the sale of the products and the sorting and recycling of the waste.

Table 4 shows the sub-criteria in the left column and, in the right column, the recommendations for analysis of innovation related to environment and sustainability .

Table 4. Environment and sustainability sub-criteria and recommendations

\begin{tabular}{|c|c|}
\hline Sub-criteria & Recommendations \\
\hline $\begin{array}{l}\text { Reducing the use of materials } \\
\text { Refers to innovations relevant to } \\
\text { reducing the quantities of natural } \\
\text { resources needed to manufacture } \\
\text { packaging, reducing the amount of } \\
\text { energy used, reducing air } \\
\text { pollution, reducing the volume of } \\
\text { waste and reducing freight } \\
\text { transport. }\end{array}$ & $\begin{array}{l}\text { - Reduce the amount of raw materials needed to manufacture } \\
\text { packaging by optimizing the use of paper in structural designs or by } \\
\text { reducing the weight (paper gram weight), reducing the amount of } \\
\text { scraps (paper scraps). } \\
\text { - Produce compact packaging, reducing volume and optimizing } \\
\text { spaces in transportation and storage, resulting in a reduction of } \\
\text { energy and air pollution. } \\
\text { - Do not use sub-packages (cradles) or replace them with economical } \\
\text { structural projects, regarding the use of paper. } \\
\text { - Reduce the use of paper bleached with chlorine and the use of } \\
\text { paints and varnishes. }\end{array}$ \\
\hline $\begin{array}{l}\text { Reuse } \\
\text { Refers to the innovations } \\
\text { pertaining to the reuse of } \\
\text { (returnable) packaging for the } \\
\text { same use after cleaning; the } \\
\text { development of smaller packages } \\
\text { to serve as refills; and the reuse of } \\
\text { packaging for other purposes. }\end{array}$ & $\begin{array}{l}\text { - Produce packaging that can be used several times by the same } \\
\text { product after a quick cleaning and that have a collection point that } \\
\text { guides and encourages consumers for this purpose. } \\
\text { - Invest in packaging that can be used as refill, but that is more } \\
\text { economical and uses less materials than the original packaging. } \\
\text { - Reuse the packaging after the product has been used, extending its } \\
\text { life cycle. Examples: paper chests, decorative accessories, } \\
\text { handicrafts, collectibles, among others. }\end{array}$ \\
\hline $\begin{array}{l}\text { Recycling } \\
\text { Refers to innovations pertinent to } \\
\text { the correct disposal of the } \\
\text { packaging, avoiding that they } \\
\text { become finished residues. } \\
\text { Measures to optimize packaging } \\
\text { recycling may occur through } \\
\text { correct identification of the } \\
\text { materials on the packaging; } \\
\text { facilitating the separation of } \\
\text { different materials; encouraging } \\
\text { the compaction of bulky packages, } \\
\text { which reduces the cost of } \\
\text { transport; and choosing } 100 \% \\
\text { recyclable raw materials. }\end{array}$ & $\begin{array}{l}\text { - Search for spaces that facilitate communication about the types of } \\
\text { materials contained in the packaging and the development of stamps } \\
\text { and identification icons about recycling. } \\
\text { - Think of structural projects that contemplate the compacting of the } \\
\text { packaging and that can be dismantled, facilitating the transport for } \\
\text { recycling. } \\
\text { - Use of recycled or recyclable materials in the design of the } \\
\text { packaging; do not use mix raw materials; opt for materials that can } \\
\text { be easily separated; and conduct research on sustainable raw } \\
\text { materials available in the market. }\end{array}$ \\
\hline
\end{tabular}

\subsection{Market}

This guideline refers to innovations relevant to the display of the packaging at the stores, including the construction of the company image (branding), aspects related to communication and marketing, packaging as a sales instrument, and analyzes it as a component of the product cost and how it influences the purchase decision. Bonsiepe (2008) refers to it in his "vectors for design innovations" as innovation based on symbolic value or status, referring to artifacts that give a certain status to those who have them; on tradition, as a cultural manifestation; on branding, turning the brand as a generator of new concepts; on trends, piggybacking on a current concept; on art; and on criticism. Camilo (2009) brings this issue in his "directions to seek innovation" as an increase in shelf life, preserving the physical and visual integrity of the packaging and optimizing spaces in the shelves; improving its presentation, transmitting innovation and performance to the product and delighting the consumer with an accessory, inserting a prize in the packaging. Verganti (2012) points out that the "market-driven" consumer-centered innovation is a different proposition from design-driven 
innovation, which is driven by trends rather than directly by the consumer. According to Mestriner (2007), packaging is consolidated as a powerful marketing tool and is employed in every way in the task of taking the product to consumers, winning their preference and maintaining their loyalty. It is also used as a competitive differential by incorporating innovation and design as regular components in its design.

Table 5 shows the sub-criteria in the left column and, in the right column, the recommendations for the assessment of market-driven innovation.

Table 5. Market sub-criteria and recommendations

\begin{tabular}{|c|c|}
\hline Sub-criteria & Recommendations \\
\hline $\begin{array}{l}\text { Branding } \\
\text { Refers to innovations pertinent to } \\
\text { actions that promote the positive } \\
\text { image of the company in the } \\
\text { market with the use of spaces in } \\
\text { the packaging for interaction with } \\
\text { the customer, creating } \\
\text { relationships with other brands and } \\
\text { encouraging the participation of } \\
\text { consumers. }\end{array}$ & $\begin{array}{l}\text { - Look for available spaces in the package to promote institutional } \\
\text { campaigns such as inserting missing persons ads in milk cartons; talk } \\
\text { about the company on the packaging; encourage the use of websites } \\
\text { to enhance customer relationships and promote sustainability issues. } \\
\text { - Build relations with other companies through joint actions, such as } \\
\text { the case of the soda campaign that encouraged the consumption of } \\
\text { pizza with soda, or the case of Brastemp washing machines which } \\
\text { indicate, through a sticker glued to the machines, the use of a specific } \\
\text { brand of soap. } \\
\text { - Encourage consumer participation by creating spaces to post } \\
\text { customer opinions; disseminate other company communication } \\
\text { channels on the packaging and look for other ways to expand this } \\
\text { institutional space. }\end{array}$ \\
\hline $\begin{array}{l}\text { Communication and marketing } \\
\text { Refers to innovations relevant to } \\
\text { the use of packaging as a channel } \\
\text { of communication between the } \\
\text { company and the customer and in } \\
\text { promoting actions that facilitate } \\
\text { the sale of the product. }\end{array}$ & $\begin{array}{l}\text {-Observe the packaging as a means to advertise other company } \\
\text { products or to disclose the available packaging sizes ( } 500 \mathrm{~g}, 1 \mathrm{Kg} \text {, } \\
5 \mathrm{Kg} \text { ) or the product flavors (strawberry, chocolate, vanilla). Integrate } \\
\text { the packaging into advertising campaigns, showing it in all } \\
\text { communication vehicles in which the company is advertising. } \\
\text { - Think of creative promotional actions through kits (take } 3 \text {, pay for } \\
\text { 2); utility packages (objects, decorative); collectibles (packaging with } \\
\text { World Cup teams); free sample (liquid detergent that comes with a } \\
\text { sponge, or a larger quantity of product for the price of the normal } \\
\text { quantity); gift tokens (for example, numbers to compete for } \\
\text { sweepstakes); commemorative packages; activities and jokes printed } \\
\text { on the packaging; and the use of famous characters or artists. }\end{array}$ \\
\hline $\begin{array}{l}\text { Reduce packaging costs } \\
\text { Refers to innovations pertinent to } \\
\text { the reduction of packaging costs, } \\
\text { improving the competitiveness of } \\
\text { the product in the market. }\end{array}$ & $\begin{array}{l}\text {-Verify the use of less expensive materials to generate competitive } \\
\text { advantage for the product in the market, but without losing quality } \\
\text { and without compromising the integrity of the product. } \\
\text { - Think of economic packages (more volume of product decreasing } \\
\text { the unit value) or refills to gain financial advantage (in the packaging } \\
\text { industry, due to operational costs, a pack containing } 200 \mathrm{~g} \text { of a } \\
\text { product is less expensive than two packs of } 100 \mathrm{~g} \text { with the same } \\
200 \mathrm{~g} \text { ). }\end{array}$ \\
\hline
\end{tabular}

\subsection{Morphology}

This guideline refers to innovations relevant to the parts that make up the packaging. To assist in the design and analysis of packaging, it is necessary to understand its graphic elements. Morphological analysis, according to Bonsiepe (1984), serves to recognize and understand the formal structure (formal conception) of a product, that is, its composition. It also includes information on surface finishes and treatments. Bonsiepe (2008) refers to it in his "vectors for design innovations" as form-based innovation, referring to new formats for existing products. Mestriner (2002) presents this issue in the "fields where to seek innovation" as colors, textures, images and visual effects and surface treatment such as metallization, holographs and textures in the packaging, and the insertion of images representing the product. Verganti (2012) points out the morphological aspects as "design-driven innovation" through 
the project processes. Table 6 shows the sub-criteria in the left column and, in the right column, the recommendations for assessing morphology innovation.

Table 6. Morphology sub-criteria and recommendations

\begin{tabular}{|c|c|}
\hline Sub-criteria & Recommendations \\
\hline $\begin{array}{l}\text { Form } \\
\text { Refers to innovations pertinent to } \\
\text { the structural design of the } \\
\text { packaging, promoting new opening } \\
\text { and closing systems; security } \\
\text { locks; displays and different } \\
\text { formats. }\end{array}$ & $\begin{array}{l}\text { - Use systems for opening and closing the packaging that facilitates } \\
\text { assembly and disassembly, and that can be opened and closed several } \\
\text { times while the product is in use. } \\
\text {-Use security locks or locks that report when there has been a } \\
\text { violation in products that need increased security or to hinder the } \\
\text { possibilities of tampering. } \\
\text { - Think of other formats for supporting elements like displays and } \\
\text { latches than the traditional square or rectangular. The use of } \\
\text { structural projects that differentiate the product in stores is an } \\
\text { excellent resource. }\end{array}$ \\
\hline $\begin{array}{l}\text { Visual aspects } \\
\text { Refer to innovations pertinent to } \\
\text { the graphic elements printed on the } \\
\text { packaging, such as brand, } \\
\text { photography, colors, among others. }\end{array}$ & $\begin{array}{l}\text { - Pay attention to how the product brand is displayed on the } \\
\text { packaging. } \\
\text { - Check the possibilities of putting images on the packaging, either } \\
\text { by interacting the product with the image or by choosing an unusual } \\
\text { way of representing the product. Images can synthesize an idea and } \\
\text { communicate it quickly and effectively. } \\
\text { - Apply colors as an aid in brand identity or product representation. } \\
\text { Colors, when used properly, can differentiate a product from the } \\
\text { competition. }\end{array}$ \\
\hline $\begin{array}{l}\text { Special effects } \\
\text { Refers to innovations relevant to } \\
\text { the sensory elements that surround } \\
\text { the packaging (touch, smell, sight, } \\
\text { hearing and taste), sharpening the } \\
\text { consumers' perception and the } \\
\text { senses. }\end{array}$ & $\begin{array}{l}\text { - Use special textures, like plastic laminations, localized varnishes, } \\
\text { low and high relief and other coatings that simulate egg shell or } \\
\text { orange peel (PROLAN), for example. } \\
\text { - Invest in finishes that bring visual effects, such as holographic } \\
\text { coatings, 3D and metallic image application. } \\
\text { - Use materials to which scents can be added, such as paints and } \\
\text { papers. It is possible to find non-toxic materials to make edible } \\
\text { packages. Apply new technologies that make sounds, like Nescafé } \\
\text { commemorative packaging, whose lid is an alarm clock. }\end{array}$ \\
\hline
\end{tabular}

\subsection{Usability}

This guideline refers to innovations relevant to the interaction of the packaging with the user, regarding the adaptations of the packaging to the habits of consumers, responding to the changes in the social trends and the adaptation of the packages to the people with special needs, such as blind and obese people and the elderly. Usability also addresses the primary functions of packaging (contain, protect and transport) referring to the maintenance of the integrity of the packaged product and the protection, comfort and safety of the user. According to Coelho (2011), the concept of usability deals with the adequacy between the product and the tasks for which it is intended, with the user that will use it, and the suitability for the context in which it will be used.

Bonsiepe (2008), in his "vectors for design innovations", calls it a user-based innovation, referring to artifacts that facilitate interaction with the user. Camilo (2009) talks about this issue in his "directions to seek innovation", referring to the increase of protection and security, maintaining the integrity of the product and the consumer, avoiding waste and leaks, keeping the product fresh for longer by improving barriers against light, moisture and other weather-related issues, facilitating the use, improving the ergonomic aspects of the packaging and the opening and closing system and following the lifestyle and habits of the users, referring to the adaptation of the packaging to the consumer, promoting a better interaction with special-needs people. Mestriner (2002) presents this issue in his "fields where to seek innovation" as devices for opening and closing, improvements in practicality and convenience, and eliminating the need for tools and devices to close packages in use. Table 7 shows the sub-criteria in the left column and, in the right column, the recommendations for assessing usability innovation. 
Table 7. Usability sub-criteria and recommendations

\begin{tabular}{|c|c|}
\hline Sub-criteria & Recommendations \\
\hline $\begin{array}{l}\text { Interaction of the package with } \\
\text { the user } \\
\text { Refers to innovations pertinent to } \\
\text { adapting the packaging to the } \\
\text { cognitive, physical and cultural } \\
\text { characteristics of the users. }\end{array}$ & $\begin{array}{l}\text { - Adapt the packaging to the behavior of consumers, as each has specific } \\
\text { values and needs. For example, sports packages with more practical caps } \\
\text { for liquids, and sunscreens with a strap to hang in the backpack; } \\
\text { packages for singles or couples without children with individual portions } \\
\text { or reduced quantity, avoiding waste. } \\
\text { - Use convenient packaging to consume products at any time or place, } \\
\text { such as packages of processed cheese (Pollen), dehydrated fruits and } \\
\text { yogurts. } \\
\text {-Think of people with special needs, inserting Braille code in the } \\
\text { packages, improving the legibility and clarity of information for the } \\
\text { elderly and inserting important information to help in the diet of obese } \\
\text { people or people with food restrictions. }\end{array}$ \\
\hline $\begin{array}{l}\text { Protection and safety of the } \\
\text { enclosed product } \\
\text { Refers to relevant innovations to the } \\
\text { primary functions of packaging } \\
\text { (containing, protecting and } \\
\text { transporting), as they relate to } \\
\text { maintaining the integrity of the } \\
\text { product. }\end{array}$ & $\begin{array}{l}\text { - Protect the product against bacteria and fungi; keep water, light, dust or } \\
\text { moisture (frozen packaging) and odor, gas and water away from the } \\
\text { product. } \\
\text { - Place seals to prevent leakage, use safety locks to prevent improper } \\
\text { opening, such as those used in medicine packaging, and use burglary } \\
\text { security devices such as encrypted and tamper-evident tags. }\end{array}$ \\
\hline $\begin{array}{l}\text { User protection and safety } \\
\text { Refers to innovations pertinent to the } \\
\text { practicality and functionality of the } \\
\text { packaging, such as handling and } \\
\text { opening the package and using } \\
\text { security devices to maintain the } \\
\text { physical integrity of the user. }\end{array}$ & $\begin{array}{l}\text { - Improve the opening and closing devices of the package with caps that } \\
\text { open and close with slot and can be opened without using tools, such as } \\
\text { openers or corkscrew. } \\
\text { - Create devices to pick up and carry the package that do not slip from } \\
\text { the hands and that can have some type of anatomical support for the } \\
\text { load. Use hooks and holders that have a hanging opening of adequate } \\
\text { size and design and that do not tear or deform the package and have the } \\
\text { appropriate strength to support the weight of the product. } \\
\text { - Place devices such as nozzles and measuring caps that allow dosing the } \\
\text { right amount of product, such as drops and measuring spoons or lids. } \\
\text { - Use security seals and seals to avoid product tampering, such as } \\
\text { holographic seals; adhesive tape printed with the name of the brand or } \\
\text { product; sealing wax; straps that fit and lock; metal-reactive paint (which } \\
\text { reacts when in contact with metal), used in medicine packaging. }\end{array}$ \\
\hline
\end{tabular}

\section{Reference interpretation}

This section reports the tests and interprets relative the packaging innovation analysis guidelines. For this purpose, the packaging awarded by ABRE (Brazilian Packing Association) in its last edition, held in 2016, was selected for sampling. The ABRE exists since 1967 with the purpose of promoting the development of the packaging market and the activities of its associates at the national and international levels. The ABRE Prize for Brazilian Packaging was created in 2001 and during this period has already awarded companies of all sizes, showing that good packaging is fundamental for all types of products of various categories, improving people's quality of life (www.premioabre.org.br).

The ABRE 2016 award received 300 packages divided into twenty-eight (28) categories, and awarded sixty-seven (67) packages, one (1) standout professional, one (1) consumer goods industry and three (3) student projects, totaling seventy-eight (78) winners. Of the seventy-two (72) prize packages, twentytwo (22) were classified as Gold, twenty-one (21) as Silver and twenty-six (26) as Bronze.

The consumer packages classified as Gold and made of paperboard were considered for this analysis, totaling eight (8) packages. The analysis of the paperboard consumer packaging awarded by ABRE in 2016 was carried out, in some cases, through the physical packaging available on the market or, in other cases, through images. Information on the challenges and results contained in the packaging was extracted from the ABRE website. Figure 2 shows the packages selected for analysis: 


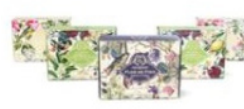

Dani Fernandes Soap

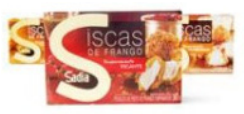

Sadia Crispy Chicken

Tenders

Source: Authors

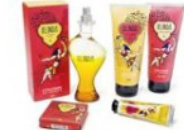

Olinda

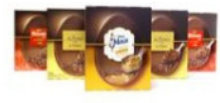

Nestlé Chocolate Cream Filled Easter Eggs
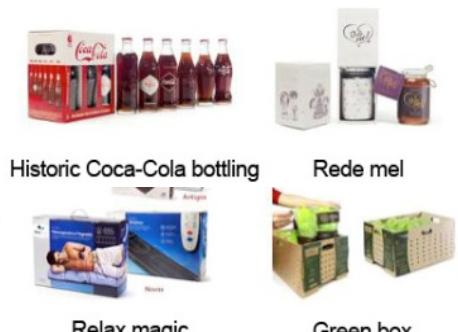

Relax magic

Green box

Figure 2. Packages selected for analysis

The Dani Fernandes soap packaging presented two incremental innovations: one regarding technological aspects, in the subcategory of production processes, bringing a special finish texture called embossing to the soap category, and another regarding environment and sustainability, proposing the packaging be reused as a decorative object for the bathroom. The Rede Mel packaging presented a market innovation, with the sub-criterion branding, by proposing a collaborative packaging with the social objective of assisting an NGO aimed at supporting the homeless. The Sadia empanada bites packaging presented an incremental innovation in the morphology category, subcategory visual aspects, by placing the brand mark throughout the height of the front panel. The Nestlé packaging innovated in the technological aspect, by mixing matte varnish with metallic coating to present a sophisticated packaging, adding value to the product. Finally, the Caixa Verde packaging presented two incremental innovations: in the morphological aspect, related to the shape of the packaging, to maintain the integrity of the product, holes were placed for ventilation, and to help with the stacking, fittings in the bottom and top were added; the structural design placed 4 handles improving usability regarding the interaction of the packaging with the user, providing more handle options. The Olinda, historic Coca Cola and Relax Magic packages presented no innovation.

There were 7 incremental innovation records in the analyzed packages (represented by the number in their corresponding row) Table 8. There was no incidence of radical innovation in the packages analyzed. According to Negrão and de Camargo (2008), there will hardly be a radical change in the segment of paperboard consumer packaging. This verification was useful to test the guidelines conceived throughout this study and also to verify that the Brazilian market is not very effective in the application of innovation in projects of paperboard consumer packaging.

Table 8. Assessment of packaging innovation

\begin{tabular}{|c|c|c|c|c|}
\hline \multicolumn{5}{|c|}{ Chart for assessing packaging innovation } \\
\hline \multirow[b]{2}{*}{ Criterion } & \multirow[b]{2}{*}{ Sub-criterion } & \multicolumn{3}{|c|}{ Innovation intensity } \\
\hline & & 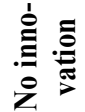 & 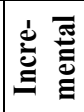 & 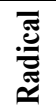 \\
\hline \multirow{3}{*}{ 1.Technology aspects } & Materials & & 1 & \\
\hline & Production processes & & 1 & \\
\hline & New technologies & & & \\
\hline \multirow{3}{*}{$\begin{array}{l}\text { 2.Environment and } \\
\text { sustainability }\end{array}$} & Reduced use of materials & & & \\
\hline & Reuse & & 1 & \\
\hline & Recycling & & & \\
\hline \multirow{3}{*}{ 3.Maket } & Branding & & 1 & \\
\hline & Communication and marketing & & & \\
\hline & Reduced packaging costs & & & \\
\hline \multirow{3}{*}{ 4.Morphology } & Form & & 1 & \\
\hline & Visual aspects & & 1 & \\
\hline & Special effects & & & \\
\hline \multirow{3}{*}{ 5.Usability } & Interaction of the packaging with the user & & 1 & \\
\hline & Protection and safety of the enclosed product & & & \\
\hline & User protection and safety. & & & \\
\hline
\end{tabular}




\section{Final thoughts}

Innovation drives competitiveness, expands markets, makes products more profitable and companies more competitive. Nowadays, innovation it is no longer just a matter of promoting improvements, it has become an obligation for the survival of companies operating in this market. Accompanying this evolutionary process, packaging has undergone great changes in design. Several functions were added to its primary functions, and innovations were applied, driven by market needs. Packaging can innovate in technological aspects, issues related to the environment and sustainability, market performance, parts that compose it and the interaction with the product and the user.

The guidelines proposed represent the points of view of designers or people responsible for the projects in general, reflecting aspects related to the work of this professional in the market. However, they should not be viewed dogmatically. For example, regarding the recommendations, they should be read as advices, an indications, a reminders, examples of situations where innovation has already been observed. The packages analyzed in this research did not present any radical innovation, that is, an innovation that modifies the way things are seen or used, representing a drastic change in the way in which the product or service is consumed, modifying the current business model. Through the guidelines presented, it was possible to verify the incidence of innovation (absence or intensity of the factor) in the field of paperboard consumer packaging.

This research contributed to the theme of Innovation in design projects, and it can be used by scholars and specialists who work in the area of development as an instrument to assist in the promotion of innovation. As a future study, we intend to continue the research proposed here, both in order to verify the incidence of innovation using other research methods, and to extend it to all types of materials used to manufacture packages, as well as other design projects.

\section{References}

Bezerra, C. (2011), A máquina de inovação: mentes e organizações na luta por diferenciação, Bookman, Porto Alegre. Bonsiepe, G. (1984), Metodologia experimental: desenho industrial, CNPQ, Brasília.

Bonsiepe, G. (2011), Design, cultura e sociedade, Blucher, São Paulo.

Camilo, A.N. (2009), Embalagens de papel cartão, papel e microondulado, Instituto da embalagem, Barueri.

Camilo, A.N. (2011), "O mercado de embalagem no Brasil e no mundo", In: Camilo, A.N. (Ed.), Embalagens: design, materiais, processos, máquinas e sustentabilidade, Instituto de Embalagens, Barueri, pp. 31-34.

Christensen, C.M. (1997), O dilema da inovação: quando novas tecnologias levam a empresas ao fracasso, Makron, São Paulo.

Coelho, L.A.L. (2011), Conceitos-chave em design, PUC-Rio, Rio de Janeiro.

Drucker, P.F. (2005), Inovação e espírito empreendedor: prática e princípios, Thomson Learning, São Paulo.

Gil, A.C. (2010), Como elaborar projetos de pesquisa, Atlas, São Paulo.

Gurgel, F.A. (2007), Administração da embalagem, Thomson, São Paulo.

Kotler, P. and Trias de Bes, F. (2011), A bíblia da inovação, Leya, São Paulo.

Mattos, J.F., Stoffel, H.R. and Teixeira, R.A. (2010), Mobilização empresarial pela inovação: cartilha: gestão da inovação, Confederação Nacional da Indústria, Brasília.

Mestriner, F. (2002), Design de embalagem: curso básico, Pearson Makron Books, São Paulo.

Mestriner, F. (2005), Design de embalagem: curso avançado, Pearson Makron Books, São Paulo.

Mestriner, F. (2012), “O design no setor da embalagem”, In: Aspectos do design II: textos compilados pelo Serviço Nacional de Aprendizagem Industrial (São Paulo), SENAI SP, São Paulo.

Negrão, C. and de Camargo, E.P. (2008), Design de embalagem: do marketing à produção, Novatec, São Paulo.

Peltier, F. and Saporta, H. (2009), Design sustentável: caminhos virtuosos, Senac, São Paulo.

Pereira, J.L. (2003), Planejamento de embalagens em papel, 2AB, Rio de Janeiro.

Schumpeter, J.A. (1982), A teoria do desenvolvimento econômico, Abril cultural, São Paulo.

Tidd, J. Bessant, J. and Pavitt, K. (2008), Gestão da inovação, Bookman, Porto Alegre.

Verganti, R. (2012), Design-driven innovation: mudar as regras da competição: a inovação radical do significado de produtos, Canal certo, São Paulo.

Ricardo Marques Sastre, Master in Design - Professor

Universidade Federal do Rio Grande do Sul - UFRGS, Departamento de engenharia de produção e transportes

Rua Duque de Caxias, 512 ap 302, 90010280 Porto Alegre, Brazil

Email: ricsastre@gmail.com 